\title{
The Effectiveness of Using Edmodo as an Online Learning Platform in Covid-19
}

\author{
*Nur Ihsan Halil \\ Language and Literature Education Study Program, FKIP, Universitas Sembilanbelas November \\ Kolaka. Jl. Pemuda No. 339, Kolaka, Indonesia 93561 \\ *Corresponding Author e-mail: nurihsanh101@gmail.com
}

Received: October 2020; Revised: November 2020; Published: November 2020

\begin{abstract}
This study aimed to describe the effectiveness of using Edmodo, as one of the online learning platforms, in the lecture process at the Faculty of Teacher Training and Education of the Universitas Sembilanbelas November Kolaka (USN Kolaka). A sample of 124 students from a total of 1,606 FKIP students of USN Kolaka participated in this study by filling out questionnaires distributed online. Student responses were analyzed descriptively quantitatively to determine the effectiveness of the implementation of learning, in terms of two aspects (the level of student participation, and the attitude of students towards the implementation of lectures). The results of data analysis showed that online learning using Edmodo at FKIP USN Kolaka has been carried out effectively. The effectiveness of using Edmodo is due to its practicality (simple display, provides various features, and supports various file types), as well as the accessibility of its use (accessible even though the connection is unstable, and saves internet quota). The convenience provided by Edmodo platform is able to increase the average participation rate of students in online learning to reach $89.18 \%$.
\end{abstract}

Keywords: covid-19; effectiveness; edmodo; online learning

How to Cite: Halil, N., I. (2020). The Effectiveness of Using Edmodo as an Online Learning Platform in Covid-19. Jurnal Penelitian dan Pengkajian Ilmu Pendidikan: e-Saintika, 4(3), 284-298. doi:https://doi.org/10.36312/e-saintika.v4i3.316

https:/ / doi.org/10.36312/e-saintika.v4i3.316

Copyright@ 2020, Halil This is an open-access article under the CC-BY-SA License.

\section{INTRODUCTION}

Corona Virus Disease 2019 (covid-19) is currently affecting 216 countries in various parts of the world, one of which is Indonesia. The Covid-19 pandemic provided extraordinary shock therapy for people around the world. Even some developed countries find it difficult to deal with the very fast and massive spread of Covid-19, such as: China, USA, Italy and Spain. Until May 16, 2020, Covid-19 has infected 4,396,392 people and caused 300,441 death (WHO, 2020). Covid-19 infection epidemic that started in China at the end of 2019 was very fast and many cases had been confirmed in all parts of the world, the median time series interval of 4 days indicated that Covid-19 was very contagious and faster and more contagious than SARS (Nishiura et al., 2020). Covid-19 has the same genome identity as SARS-Cov-2 which came from animal transmission through several causes, that infected humans, and from human transmission to other humans (Brida et al., 2020).

Covid-19 has temporarily changed society in the world. In the normal situation, the life is usually fast paced and people do not stop workingnon-stop, and the 
competition system is the main target, then the conditions for the spread of Covid-19 make a crisis situation for humans. Activities in the world become silent, slow down, and are even forced to stop for a moment in order to break the chain of the spread of Covid-19. Until 7 April 2020 Covid-19 affected the activities of 2.7 billion workers or $81 \%$ worldwide (ILO, 2020). Hubei as the first region to report positive Covid-19 immediately implements a lockdown, population activity is quiet, and the movement of people in and out is severely restricted including through international flight routes (Lau et al., 2020; Riddle et al., 2020). Lockdowns in various countries including the UK have made social and economic activities centered at home and dominant using the internet network, and reducing the use of private vehicles (Thelwall \& Thelwall, 2020; Thornton, 2020).

Indonesia, as one of the affected countries, has many challenges from the Covid19 pandemic. Indonesia's big challenges in various aspects of life, such as: economy, politics, social and education. The data until May 16, 2020, Covid-19 in Indonesia has infected 17,025 people and resulted in 1,089 deaths (GTPPC, 2020). The impact of Covid-19 on the economic aspect caused many economic activities stop, such as industries, trades, and other economic activities, even the state had to provide funds to help the lives of people who were laid off or unable to work (Thorik, 2020). Many political policies were highlighted in the Covid-19 era, especially with regard to efforts to deal with the Indonesian government (Arum, 2020). The policy of releasing assimilation program inmates was considered ineffective since many ex-convicts did crime again and caused social unrest in society in this difficult time due to Covid-19 effect (Anwar, 2020).

This research focussed on the effect of Covid-19 on the aspect of education which is one of the benchmarks for the human development index in the world. The indicators of the Human Development Index are the health sector, the education as well as knowledge sector, and the economic sector (Elistia \& Syahzuni, 2018). Education during the Covid-19 period must be carried out from home, so it must be based on online learning with all the obstacles faced regarding readiness and internet networks (Khasanah et al., 2020).

The efforts of the government of the Republic of Indonesia in reducing the rate of spread of covid-19 desease by issuing appeals in the forms of social distancing policies, physical distancing or avoiding crowds and maintaining distance or physical contact between humans. The Ministry of Education and Culture (Kemendikbud) through circular number 3 of 2020 gives a warning regarding the prevention of Covid-19 but direct learning is still being carried out. In circular number 4 of 2020, an Education policy appears in the emergency period of the spread of Covid-19 which contains the cancellation of the 2020 National Examination, learning from home through online or remote learning, eliminating direct mass-gathering students related to school exams, class promotions, and acceptance of new students. Furthermore, the circular letter issued by the Directorate General of Higher Education (Dirjen Dikti) number 1 of 2020 contains the implementation of online lectures via the platform: Google Classroom/ Edmodo/ Schoology/ Classdojo.

The Ministry of Education and Culture's policy is the legal basis for several universities in Indonesia to issue derivative regulations in an effort to deal with the Covid-19 pandemic. One of the tertiary institution that implements a study from home policy for students and Work from Home $(\mathrm{WfH})$ for lecturers is Universitas 
Sembilanbelas November Kolaka (USN Kolaka) through the Rector's circular letter No.284/UN56/KP/2020. All lecture activities are carried out online.

The implementation of online learning from home policy that is applied suddenly made students not fully accustomed to undergoing online lectures and tended to be very poorly prepared both in terms of mastering the initial material and also when learning took place. As an initial illustration for comparison, prior to the pandemic, lecturing activities at FKIP USN Kolaka were mostly conducted in offline class or face-to-face in the classroom between tecturers and students which was carried out through various learning models. The learning model applied includes discovery learning which is used in science learning at FKIP USN Kolaka to improve student process skills as described in Sukariasih et al (2019) that guided discovery can improve physics science process skills; this is in line with what was stated by Hunaidah et al (2019) and Retnawati et al (2019) that discovery learning has a significant effect on science process skills and students' conceptual mastery. In addition, problem-based learning or problem solving is also often applied to improve students' thinking skills as described in research of Djidu and Jailani (2017); Saputra and Sukariasih (2019) that was found out that creative problem solving learning can improve students' critical thinking skills in physics.

The comparison of data on the application of learning methods before the pandemic explains that the habits of learners or students, to receive lecture materials maximally are carried out by the offline class method or face to face directly in the room or class. Due to this reason, when online learning was implemented, it was immediately applied during the pandemic period which created problems for students from various aspects. Not only students, but also lecturers are not ready to implement an online system in the learning process. The indoor and outdoor direct learning affected the students understanding more about the material (Nursalam et al., 2020; A E Sejati et al., 2019; Sejati et al., 2016). The most important learning during pandemic is preparation for dealing with online equipment (Anhusadar, 2020).

Online-based learning has been applied to several courses at USN Kolaka, but for the implementation of online-based learning to whole courses in USN Kolaka is completely new. Online learning is a surprise effect of the Covid-19 pandemic which needs to increase the readiness of users and facilities so that it can be a solution to learning problems in the midst of a pandemic, such as in research of Darmalaksana (2020) explaining that online learning during the WFH (Work From Home) period during the Covid pandemic -19 in the hadith research method course took place effectively in reaching the learning outcomes in the form of exercise worksheet for writing hadith research proposals. E-learning is a way out in a disaster emergency such as the case in New Zealand due to the 2011 earthquake (Ayebi-Arthur, 2017). In developing countries context, students' acceptance of e-learning is low. $70.6 \%$ of schools outside Bangkok were unprepared due to limited network access and outdated computer equipment (Ngampornchai \& Adams, 2016). The low technology skills were one of the challenges in e-learning (Rahmawati, 2016; Retnawati et al., 2020).

Readiness is in the form of studying the use of applications, especially platforms that have been determined by the Directorate General of Higher Education. Equal tandards of attendance and assignments that are not yet similar to other subjects create problems that cause students having too many tasks. The material delivery 
standards that are not uniform also cause obstacles for students to understand the material. E-learning tends to be interpreted by students as individual or group assignments that are increasing in number, and the time to finish the assignments is really short (Apuke \& Iyendo, 2018).

Network problems and internet quota are also major considerations in the application of online-based learning. The use of a web-based learning model online makes students sometimes find it difficult to understand the explanation given by educators due to the limitations of the internet or the use of android. This is also an obstacle when delivering lecture materials online. However, it is different from the video conferencing method on several other online learning platforms. In terms of delivery, the displayed material at the video conference is easy to understand because it is direct face to face video interaction, but it requires a good network connection and a lot of data packets (Wirani, 2020). Slow network and internet provider costs are weaknesses in the delivery of online learning, especially videobased ones (Apuke \& Iyendo, 2018; Rahmawati, 2016). The existence of an internet network is a major component in assessing the feasibility of using e-learning (Kusmana, 2011).

There are several efforts to face various problems in the application of online lectures, namely choosing a platform that is easy to implement, easy to access, and minimum internet quota usage. The platform can foster student interest and enthusiasm for learning. One of the platforms chosen by USN Kolaka Teacher Training and Education Faculty (FKIP) is Edmodo. Edmodo platform has advantages in terms of being communicative and interactive and is equipped with communication facilities between fellow teachers, fellow students, between teachers and students, and parents of students or students can be directly involved in the platform as controlling to monitor the learning process. Edmodo is easy to use in lectures, informative, and a popular social media-based platform (Basori, 2013; Fauzi, 2017; Laili \& Nashir, 2018).

Edmodo has an attractive menu interface, simple features and has similar display to one of the social media Facebook. The icon and page that adapted Facebook made Edmodo quickly adapted by students and lecturers as users in the learning process. Online learning has the advantage. It can be applied during natural disasters such as floods or volcanic eruptions, or during non-natural disasters such as the Covid-19 pandemic emergency. Edmodo is one of the media that is often identified as Facebook in learning (Gay \& Sofyan, 2017). Learning Management System (LMS) is a portal that connects teachers and students so they can easily share subject matter or assignments outside school hours (Chaw \& Tang, 2018). LMS is able to help teachers and students interact with each other with teacher perceptionbased learning (Sujatmiko, 2017). The implementation of learning media based application give the positive impact in the learning (Nasruddin et al., 2019).

Similar to Facebook, Edmodo is easy to access and consumes low internet packages. However Edmodo does not yet provide video conferencing facilities like Moodle, Zoom, Skype, and or Microsoft Team. Edmodo's facilities are posting material, sharing videos (not conferencing), links, grades, notifications, and assignments (Etfita, 2019). One of Edmodo's weaknesses is the unavailability of video conferencing to interact directly in online learning, but the advantages outweigh the weaknesses (Ekayati, 2018). 
Based on Edmodo's strengths and weaknesses, it is necessary to conduct research related to the effectiveness of Edmodo as an online learning platform during the Covid-19 emergency at FKIP USN Kolaka. This study examines the effectiveness of Edmodo by evaluating the implementation of online lectures. The research covers what students felt and the amount of students' participation. Some research focuses on students' participation in the application of Edmodo, especially on online discussions and tasks (Gay \& Sofyan, 2017) and students' perceptions in implementing Edmodo (Alqahtani, 2019; Etfita, 2019; Fauzi, 2017; Inayati, 2019).

\section{METHOD}

This research used a quantitative. The research subjects were students of FKIP USN Kolaka who were spread across the Indonesian Language and Literature Education Study Program, Physics Education, Mathematics Education, and Geography Education. The population of FKIP students at USN Kolaka was 1,606. The sample of 124 was taken based on the formula of the deep Slovin (Setiawan, 2007). According to Harianto et al (2019); Sejati et al (2019a); Sejati et al (2020; 2017) quantitative approach describe detail phenomena with the numeral.

The data taken consisted of primary data related to student responses in the implementation of online lectures using Edmodo from March 16 to April 3, 2020. Secondary data was in the form of the number of students' participation taking part in the Edmodo application in comments and submission quizzes. The research instrument was made in the form of google form. The data were analyzed using descriptive quantitative by calculating the percentage. Percentage is one of the interesting option to describe quantitative research (Sejati et al., 2019b; Sukariasih et al., 2019).

\section{RESULTS AND DISCUSSION}

USN Kolaka FKIP lectures in normal circumstances were held at Jalan Pemuda Number 366, Kolaka Regency. The distribution of student location categories when doing online lectures using Edmodo during the Covid-19 emergency period was $41 \%$ outside Kolaka Regency with conditions in remote or rural areas and there were $21 \%$ students residing in Kolaka Regency with conditions in hinterland, rural, or remote areas. The students who were in the center of activities with a stable internet network connection in Kolaka Regency were 28.2\% and outside Kolaka Regency were $9.7 \%$. Figure 1 shown the students distribution location.

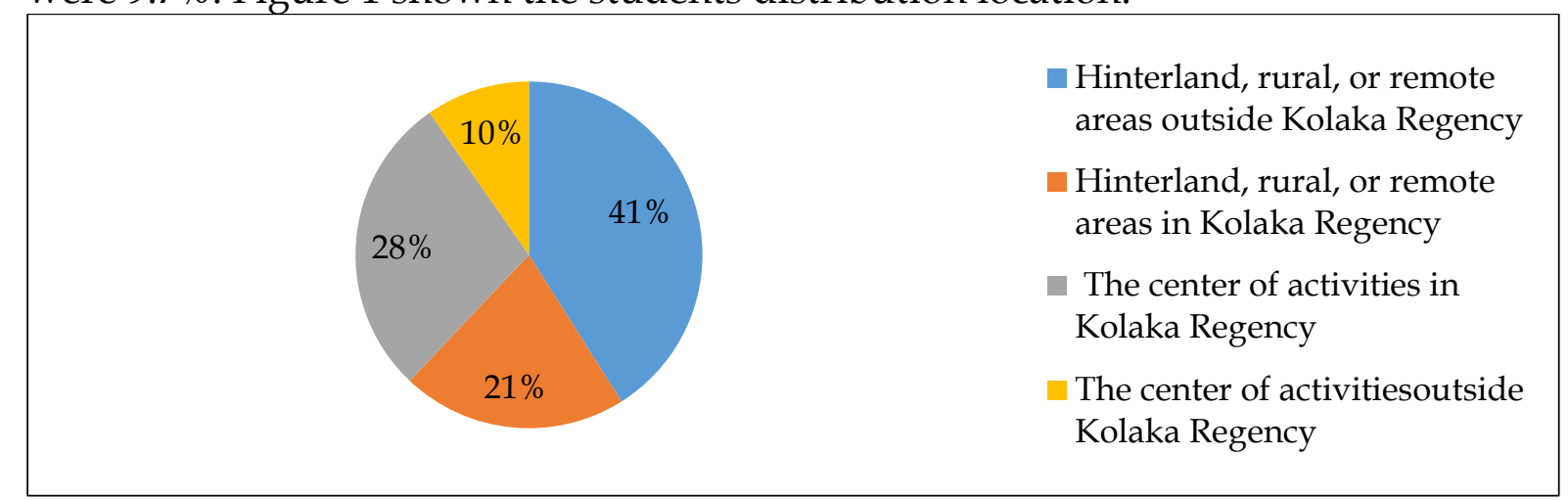

Figure 1. Students Distribution Location

Based on the location data of students when doing online lectures, it was found that $62.1 \%$ were in areas that were not equipped with good network facilities. Some areas in Southeast Sulawesi are not equipped with good signal towers, especially in 
forest or hilly areas. Online learning activities can be carried out at any time if the development of the internet network is rapid, in the sense that the network is strong or at the center of activity (Yuberti, 2015). The location of accessing online lectures can be done anywhere, but the provider signal on Edmodo affects the speed of access (Sari, 2019). In other words, it is getting slower. Figure 2 shown the students location networks facilities.

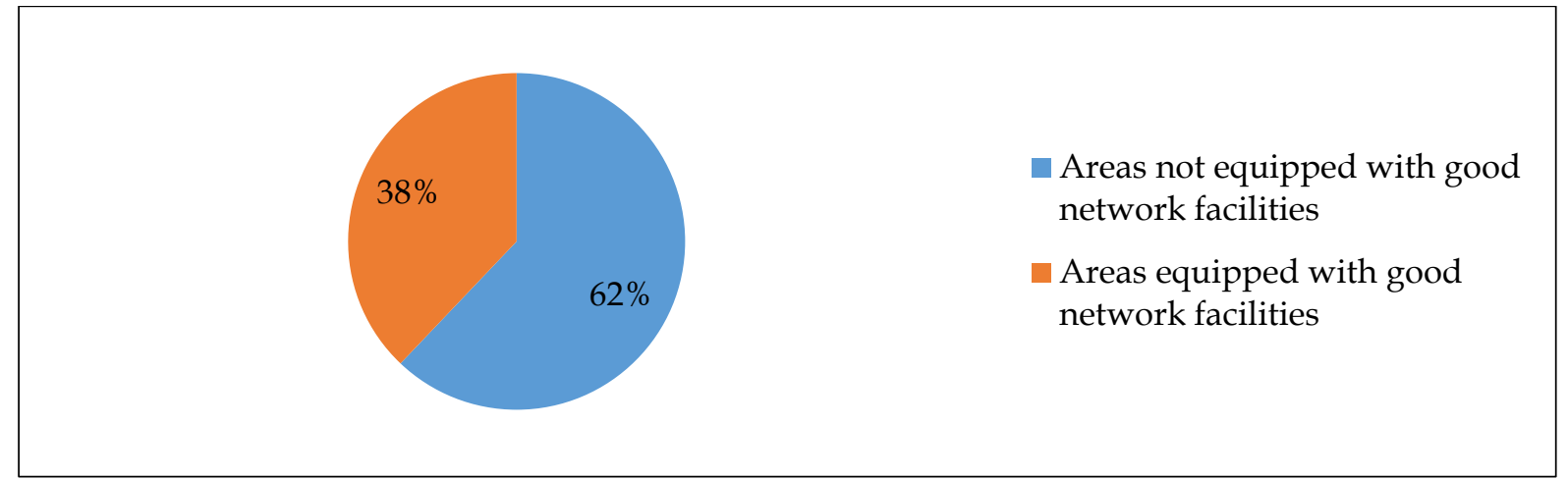

Figure 2. Students Location Networks Facilities

In terms of the accessibility of Edmodo, 59.7\% of students who accessed the application said that the application can always be accessed. Meanwhile, $26.6 \%$ of students experienced difficulties in accessing Edmodo, but the application could be accessed more often. The students who experienced problems in accessing Edmodo and were more often unable to access were 13.7\%. Figure 3 shown Edmodo accessible.

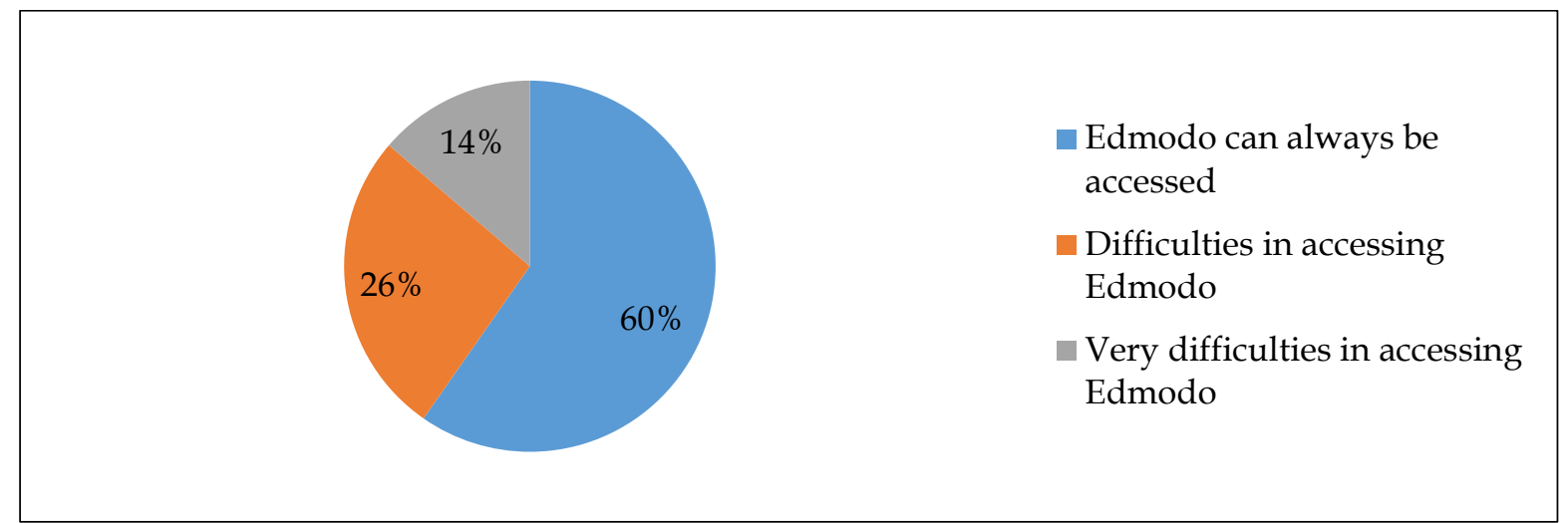

Figure 3. Edmodo Accessible

There were no students who could not always access Edmodo in online lectures. Edmodo could be accessed if there was a signal or cellular network. In a blank zone with no signal at all, of course Edmodo or other internet services could not be accessed. The majority of students were in areas where there was an internet network even though it was limited and they could take part in lessons using Edmodo even though they had to do more effort to find networks. According to Alqahtani (2019), Edmodo is very easy to access, use, and free of charge.

The application other than Edmodo, which was easier to access for online lectures for $78.2 \%$ students, was WhatsApp Group (WAG). For 13.7\% students, Zoom application was the easier one, but $6.5 \%$ students said that there was nothing more accessible than Edmodo, and 1.6\% answered the Facebook group. WAG was the most often used application by students for their daily communication. WAG 
was also the choice of some educators in delivering additional learning information. The application of lectures with WhatsApp as a supplementary support at King Khalid University had $89 \%$ results with small errors (Hassan \& Ahmed, 2018). The communication skill related to the learning process (Nasruddin \& Jahring, 2019). Figure 4 shown the application that more easy than Edmodo.

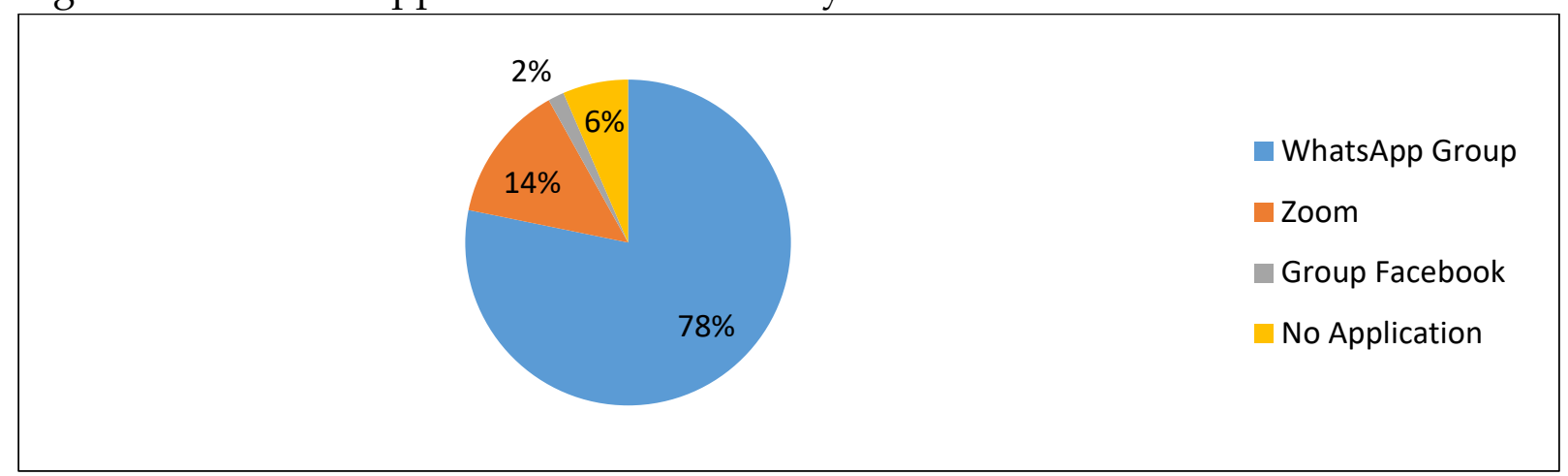

Figure 4. The Application that more Easy than Edmodo.

For $89.5 \%$ students, the application of Edmodo was easy. The reasons for 111 students who answered were easy to apply were based on three barometers namely icon, page, and steps. $64.9 \%$ students thought that the Edmodo icon was simple, $30.7 \%$ students responded that Edmodo page views were communicative, and $4.4 \%$ students answered that there were not many steps that needed to be opened and easy to use and understand. Simple and communicative icons on the page were the main reason for the speed of students adapting to online learning. Edmodo has a simple icon and is suitable for blended learning (Hourdequin, 2014). Edmodo is communicative between lecturers and students or between students and students (Laili \& Nashir, 2018). Figure 5 show reason the Edmodo was Easy.

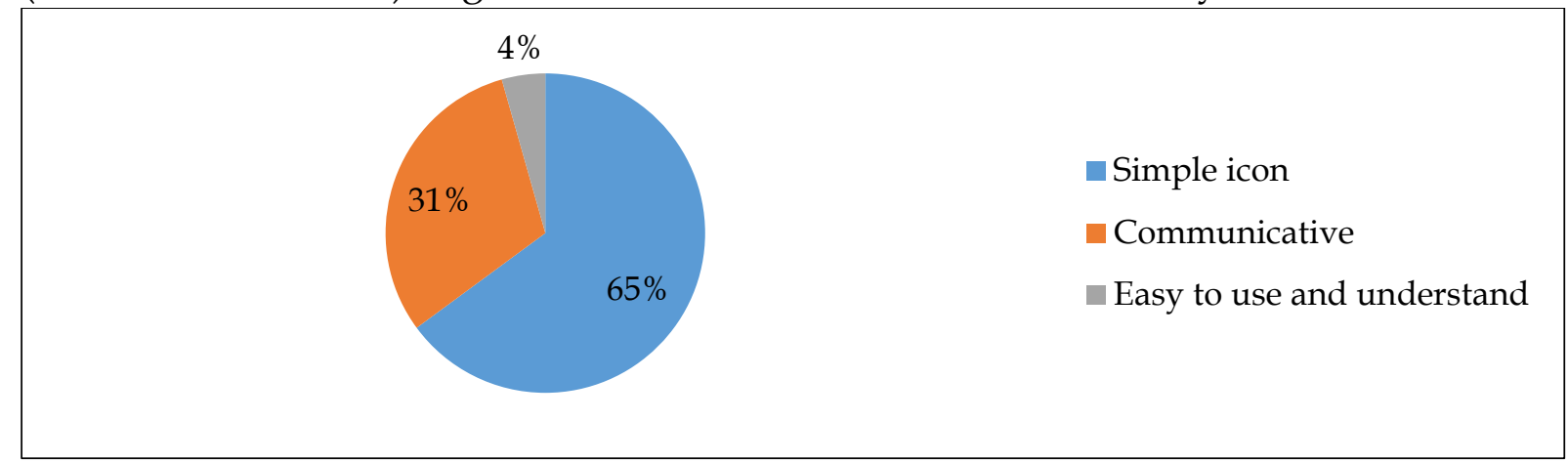

Figure 5. The reason of students choose Edmodo

In terms of the application of Edmodo, 10.5\% of students answered difficult. The reason for 13 students who answered that it was difficult to apply was because the Edmodo icon was complicated by $35.7 \%$, 25\% of the Edmodo page display was not communicative, and 39.3\% answered that the notification did not always appear and still did not understand how to apply it. The difficulty in using Edmodo for students who had never used it before was natural. This was because it was still in the process of understanding procedures or habituation for $10.5 \%$ of students who still had difficulty adapting to Edmodo. According to Saifuddin (2018), student perceptions determine the success of implementing e-learning and affect learning motivation. Figure 6 shown reason the Edmodo was not Easy. 


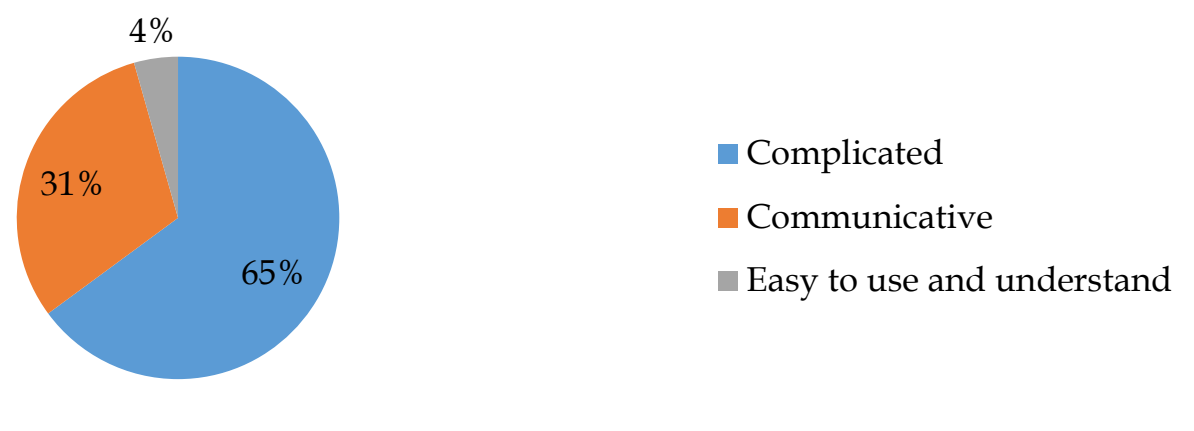

Figure 6. The reason of students not choose Edmodo

Students recommend that they continued to use Edmodo for their next online lecture (61.3\%). As many as $30.6 \%$ students recommend switching to WAG, $8 \%$ students suggested switching to Zoom, 0.8\% students expected to use Facebook groups, and $0.8 \%$ students preferred switching to a combination of WAG and zoom. 76 students who recommended sticking to Edmodo gave reasons related to network access that Edmodo was fast access and did not require a stable network. According to Dharmawati (2017), Edmodo as a Course Management System is very comprehensive with fast access and easy to use. Figure 8 shown the students recommendation to the next learning.

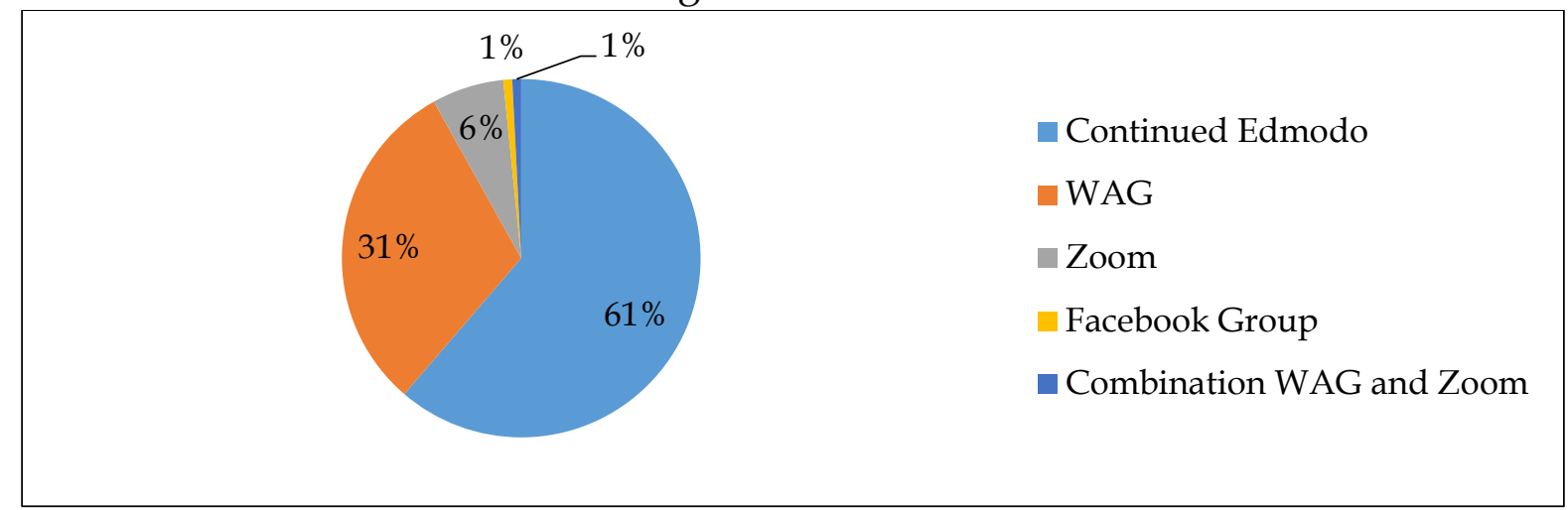

Figure 7. Students Recommendation to the Next Learning

Regarding Emodo display and content, it was easy to learn tools function and assignment submission page. In addition, material posting supported various types of files (Microsoft Word, pdf, MP3, MP4, 3GP) and learning activities were directed and organized. Furthermore, related to content, it could motivate learning English because some tools use English, so the task score could be seen to increase motivation. Edmodo is relatively easy to apply even for beginners, supports various file formats, and can be accessed using a laptop or Android gadget (Ekayati, 2017). Edmodo's feature makes the learning process interactive and makes it easier for teachers in managing learning activities (Basori, 2013).

Another main reason was because Edmodo saved internet data. Edmodo, like Facebook, did not spend a lot of internet data. Using Edomodo is more economical, private, simple, and flexible (Sujatmiko, 2017). Edmodo is similar to Facebook and many of its advantages have been reviewed in previous research (Yahfizham et al., 2018).

Students recommended switching to WAG because it was easier to network (38 students). The students were also used to use WAG. However, the weaknesses of the 
WAG especially controlling attendance and quizzes were taken into consideration. WAG was effective for complementary communication, but had many weaknesses when it was used as the main media for e-learning. According to Hassan and Ahmed (2018); Prajana (2017), using WhatsApp as a complement to learning was proven effective, but not as the main medium.

Students recommended switching to Zoom because it was more effective in receiving material using face to face video conferencing (8 students). Some students who recommended Edmodo also got the advantages of video conferencing, but did not recommend to switch to Zoom because it required a stable network and large data packets. 1 student who recommended switching to the WAG and zoom combination combined the advantages of WAG and zoom. Participants (88\%) in the zoom meeting session experienced difficulty in trying to join (Archibald et al., 2019). Edmodo only provides indirect video, either via a YouTube link or a video file, which is one of the reasons for choosing one with video conferencing (Rahmawati, 2016). The weakness of zooming on the network, if it is not strong, learning will be ineffective and even many students cannot participate in learning classes (Anhusadar, 2020).

One student recommended switching to the Facebook group because not all students had a quota and Facebook groups could be accessed without a quota. Facebook groups like WAG functioned as complementary information. In its development, Facebook is only used in account information per account. Group facilities on Facebook have started to be abandoned by most people. Facebook groups can support or complement learning at universities, but not as the main media (Ahern et al., 2016). The social media Facebook is more likely to be used for business purposes (Hu, 2011).

Student participation rates in Edmodo classes increased from week one to week three. Data on student participation rates (Table 1) showed an increase number until it reached the participation rate of $100 \%$.

Table 1. The Level of Students' Participation in Using Edmodo

\begin{tabular}{llccc}
\hline No & Activities & Participated & Not Participated & $\begin{array}{c}\text { Percentage of } \\
\text { Participation }\end{array}$ \\
\hline 1. & Materials in 1 & & & $89 \%$ \\
& week & 109 & 15 & $77 \%$ \\
2. & Quiz in 1st week & 96 & 28 & $88.9 \%$ \\
3. & Materi in 2nd week & 110 & 14 & $91 \%$ \\
4. Quiz in 2 & & 11 & $100 \%$ \\
5. & Materials in 3rd & 113 & 0 & \\
& week & 124 & & \\
\hline
\end{tabular}

The average participation rate of the material for 3 weeks was $93 \%$ with the third week achievement of $100 \%$ or all students attended Edmodo online lectures. The average participation rate for the Quiz for 2 weeks was $84 \%$ with the second week achievement of $91 \%$. The remaining $9 \%$ caould be improved by giving remedial in quiz. The average number of material and quiz participation was $89.18 \%$. in the line with the results of study, Alqahtani (2019) stated that learning 
with Edmodo can increase students' attention and a positive response to online lectures.

Based on Circular Number 326 / UN56 / KP / 2020, the participation rate of all Faculties was obtained. The lowest one was $50 \%$ or $50 \%$ of students could not study. Furthermore, this was due to unequal internet connections in the student areas. The policy taken by USN Kolaka was to stop the online lecture process until May 29, 2020. If the Covid-19 outbreak could end in early June, USN Kolaka plans to replace lectures through the short semester from June to August 2020. This was emphasized directly by the top leader of the university of USN Kolaka as an effort to provide the best solution for students who had been affected by the pandemic in catching up with college.

If Covid-19 had not ended in the June to August 2020 period, then the option to re-implement online lectures should be taken by USN Kolaka. Nuraini et al (2020) estimates that Covid-19 will end at the end of April 2020 with a note that it must be effective as the South Korean government has done, while in research (Putra \& Mohamad, 2020) it was explained that the daily number of nCOVID-19 cases in Indonesia will have the highest maximum cases of around 400 and the total number of positive nCOVID-19 positives in Indonesia will reach 12,000 with a calm period in mid-June, in fact these predictions were not accurate. To date, the increase in the number of positive confirmed cases reported by the national task force continued to experience a very high increase. In fact, the increase in the number of confirmed positive cases was approaching 1000 cases a day.

Looking at some of the various reviews about the end of the Covid-19 pandemic, it was possible for the period July to August to implement online lectures to be held again. Good student perception data and high student participation in the use of the Edmodo platform were one of the best choices for implementing online lectures during the Covid-19 emergency. The use of Edmodo lectures is more regular and progressive with the satisfaction level of STAIN Sultan Abdurrahman students reaching 91.6\% (Sari, 2019). The effectiveness of Edmodo use is higher than conventional, marked by increased participation (Nu'man, 2014).

\section{CONCLUSION}

All students of FKIP USN Kolaka could access Edmodo in their area. Edmodo was considered to have a simple icon and a communicative page display. $61.3 \%$ students recommended that they continued to use Edmodo for their next online lectures. 78.2\% students rated WAG as more accessible than Edmodo, but for online lectures it was more suitable to use Edmodo. The students gave reasons that WAG was more suitable for communication, while Edmodo with a network that was not much different could also be accessed. Other advantages offered by Edmodo were as follows. It saved internet quota and the icon was clear, directed, and organized. It supported various files. The quiz scores could be seen, and it motivated students to learn English. The level of participation was high with an average of $89.18 \%$ on materials and quizzes.

\section{RECOMMENDATION}

This research recommendation is the Edmodo platform can be one of the effective alternative to the online learning. 


\section{ACKNOWLEDGMENT}

Thanks to Universitas Sembilanbelas November Kolaka, specially FKIP for support in this paper process. Thanks to the Hasan Djidu, Nasruddin, Karman, I Gede Purwana Edi Saputra, Syarifuddin, and Andri Estining Sejati for support in the process of data collecting.

\section{REFERENCES}

Ahern, L., Feller, J., \& Nagle, T. (2016). Social media as a support for learning in universities: an empirical study of Facebook Groups. Journal of Decision Systems, 25(sup1), 35-49. https:/ / doi.org/10.1080/12460125.2016.1187421

Alqahtani, A. S. (2019). The use of edmodo: Its impact on learning and students' attitudes toward it. Journal of Information Technology Education: Research, 18, 112. https:// doi.org/10.28945/4389

Anhusadar, L. O. (2020). Persepsi mahasiswa PIAUD terhadap kuliah online di masa pandemi. KINDERGARTEN: Journal of Islamic Early Childhood Education, 3(1), 44-58. https:/ / doi.org/10.24014/KJIECE.V3I1.9609

Anwar, M. (2020). Asimilasi dan peningkatan kriminalitas di tengah pembatasan sosial berskala besar pandemi corona. Adalah: Buletin Hukum E Keadilan, 4(1), 101-106. https:/ / doi.org/10.15408/adalah.v4i1.15504

Apuke, O. D., \& Iyendo, T. O. (2018). University students' usage of the internet resources for research and learning: forms of access and perceptions of utility. Heliyon, 4(12), 1-34. https:/ / doi.org/10.1016/j.heliyon.2018.e01052

Archibald, M. M., Ambagtsheer, R. C., Casey, M. G., \& Lawless, M. (2019). Using zoom videoconferencing for qualitative data collection: perceptions and experiences of researchers and participants. International Journal of Qualitative Methods, 18, 1-8. https:/ / doi.org/10.1177/1609406919874596

Arum, R. (2020). Pembatasan sosial di Indonesia akibat virus Corona ditinjau dari sudut pandang politik. Politic Solitic. https:/ / doi.org/10.31228/OSF.IO/G8NY3

Ayebi-Arthur, K. (2017). E-learning, resilience and change in higher education: Helping a university cope after a natural disaster. E-Learning and Digital Media, 14(5), 259-274. https:/ / doi.org/10.1177/2042753017751712

Basori, B. (2013). Pemanfaatan social learning network "Edmodo" dalam membantu perkuliahan teori bodi otomotif di prodi PTM JPTK FKIP UNS. Jurnal Ilmiah Pendidikan Teknik dan Kejuruan, 6(2), 99-105. https://doi.org/10.20961/jiptek.v6i2.12562

Brida, M., Chessa, M., Gu, H., \& Gatzoulis, M. A. (2020). The globe on the spotlight: Coronavirus disease 2019 (Covid-19). In International Journal of Cardiology 310, 170-172. Elsevier Ireland Ltd. https:/ / doi.org/10.1016/j.ijcard.2020.04.006

Chaw, L. Y., \& Tang, C. M. (2018). What makes learning management systems effective for learning? Journal of Educational Technology Systems, 47(2), 152-169. https:/ / doi.org/10.1177/0047239518795828

Darmalaksana, W. (2020). Capaian pembelajaran model online masa wfh covid-19 pada mata kuliah metode penelitian hadis di UIN Sunan Gunung Djati Bandung. Karya Tulis Ilmiah (KTI) Masa Work From Home (WFH) Covid-19 UIN Sunan Gunung Djati Bandung, 1-12. http:/ / digilib.uinsgd.ac.id/30434/

Dharmawati. (2017). Penggunaan media e-learning berbasis edmodo dalam pembelajaran english for business. Query: Journal of Information Systems, 1(01), 
43-49. http://jurnal.uinsu.ac.id/index.php/query/article/view/640

Djidu, H., \& Jailani, J. (2017). Model Pembelajaran Kalkulus SMA Berbasis Masalah untuk Meningkatkan Kemampuan Berpikir Tingkat Tinggi Siswa. Parama Publishing.

Ekayati, R. (2017). Optimalisasi aplikasi edmodo dalam meningkatkan kemandirian belajar dan kesadaran berbahasa mahasiswa pada mata kuliah literary criticism di fkip UMSU. EduTech: Jurnal Ilmu Pendidikan dan Ilmu Sosial, 3(1), 148-165. https://doi.org/10.30596/EDUTECH.V3I1.992

Ekayati, R. (2018). Implementasi Metode Blended Learning Berbasis Aplikasi Edmodo. EduTech: Jurnal Ilmu Pendidikan dan Ilmu Sosial, 4(2), 50-56. https:/ / doi.org/10.30596/EDUTECH.V4I2.2277

Elistia, E., \& Syahzuni, B. A. (2018). The correlation of the human development index (hdi) towards economic growth (gdp per capita) in 10 ASEAN member countries. JHSS (Journal of Humanities and Social Studies), 2(2), 40-46. https:/ / doi.org/10.33751/jhss.v2i2.949

Etfita, F. (2019). Students' perspective on the use of edmodo as an assessment tool. JSHMIC: Journal of English for Academic, 6(1), 18-25. https://doi.org/10.25299/jshmic.2019.vol6(1).2516

Fauzi, A. (2017). The effect of edmodo on students' writing skill in recount text. IJPTE: International Journal of Pedagogy and Teacher Education, 1(2), 73-79. https://doi.org/10.20961/ijpte.v1i2.5038

Gay, E., \& Sofyan, N. (2017). The effectiveness of using edmodo in enhancing studentsâ outcomes in advance writing course of the fifth semester at FIP UMMU. Journal of English Education, 2(1), 1-11. https:/ / doi.org/10.31327/jee.v2i1.217

GTPPC. (2020). Gugus Tugas Percepatan Penanganan COVID-19. https://covid19.go.id/

Harianto, E., Nursalam, L. O., Ikhsan, F. A., Zakaria, Z., Damhuri, D., \& Sejati, A. E. (2019). The compatibility of outdoor study application of environmental subject using psychological theories of intelligence and meaningful learning in senior high school. Geosfera Indonesia, 4(2), 201-216. https:/ / doi.org/10.19184/geosi.v4i2.9903

Hassan, A. Q. A., \& Ahmed, S. S. (2018). The impact of whatsapp on learners' achievement: A case study of english language majors at King Khalid University. International Journal of English Language Education, 6(2), 69-81. https:/ / doi.org/10.5296/ijele.v6i2.13743

Hourdequin, P. (2014). Edmodo: A simple tool for blended learning. The Language Teacher, 38(1), 34-35. https://jalt-publications.org/tlt/departments/tltwired/articles/3547-edmodo-simple-tool-blended-learning

Hu, X. (2011). Social Media Business Model Analysis-Case Tencent, Facebook, and Myspace Logistics Master's thesis. Laitos: Department of Information and Service Economy Tieto-ja Palvulutalouden Laitos. https://aaltodoc.aalto.fi/handle/123456789/676

Hunaidah, M., Sukariasih, L., \& Saputra, I. G. P. E. (2019). Penerapan model pembelajaran discovery untuk meningkatkan keterampilan proses sains dan penguasaan konsep ipa peserta didik kelas viiid smp kartika XX-6 Kendari. JPFT (Jurnal Pendidikan Fisika Tadulako Online), 7(3).

ILO. (2020). ILO Monitor: COVID-19 and the world of work. 2nd Edition. https://www.ilo.org/global/about-the-ilo/WCMS_740877/lang-- 
en/index.htm

Inayati, A. M. M. (2019). Edmodo in english language learning: a review of recent studies. Khazanah Pendidikan, 12(2). https://doi.org/10.30595/jkp.v12i2.4291

Khasanah, D. R. A. U., Pramudibyanto, H., \& Widuroyekti, B. (2020). Pendidikan dalam masa pandemi covid-19. Jurnal Sinestesia, 10(1), 41-48.

Kusmana, A. (2011). E-learning dalam pembelajaran. Lentera Pendidikan: Jurnal Ilmu Tarbiyah dan Keguruan, 14(1), 35-51. https:/ / doi.org/10.24252/lp.2011v14n1a3

Laili, R. N., \& Nashir, M. (2018). The effect of blended learning by using edmodo in teaching english for nursing students. Indonesian Journal of Curriculum and $\begin{array}{llll}\text { Educational Technology } & \text { 61) }\end{array}$ https://doi.org/10.15294/ijcets.v6i2.26509

Lau, H., Khosrawipour, V., Kocbach, P., Mikolajczyk, A., Ichii, H., Schubert, J., Bania, J., \& Khosrawipour, T. (2020). Internationally lost covid-19 cases. Journal of Microbiology, Immunology and Infection. https:/ / doi.org/10.1016/j.jmii.2020.03.013

Nasruddin, N., \& Jahring, J. (2019). Efektivitas penerapan model pembelajaran reciprocal teaching dalam meningkatkan kemampuan komunikasi matematis siswa. SAINTIFIK, 5(1), 27-35. https:/ / doi.org/10.31605/saintifik.v5i1.195

Nasruddin, N., Mashuri, S., \& Jahring, J. (2019). Implementation of team assited individualization instructional strategies supported by geogebra software to improve mathematical problem solving ability. Jurnal Pendidikan Progresif, 9(1), 16-21. https:/ / doi.org/10.23960/jpp.v9.i1.201903

Ngampornchai, A., \& Adams, J. (2016). Students' acceptance and readiness for elearning in Northeastern Thailand. International Journal of Educational Technology in Higher Education, 13(1), 34. https:/ / doi.org/10.1186/s41239-016-0034-x

Nishiura, H., Linton, N. M., \& Akhmetzhanov, A. R. (2020). Serial interval of novel coronavirus (covid-19) infections. International Journal of Infectious Diseases, 93, 284-286. https:// doi.org/10.1016/j.ijid.2020.02.060

Nu'man, A. Z. (2014). Efektifitas penerapan e-learning model edmodo dalam pembelajaran pendidikan agama islam terhadap hasil belajar siswa (Studi kasus: smk muhammadiyah 1 Sukoharjo). In DutaCom Journal, 7(1).

Nuraini, N., Khairudin, K., \& Apri, M. (2020). Modeling simulation of covid-19 in Indonesia based on early endemic data. Communication in Biomathematical Sciences, 3(1), 1-8. https:/ / doi.org/10.5614/CBMS.2020.3.1.1

Nursalam, L. O., Harianto, E., Hasan, M., \& Sejati, A. E. (2020). Nilai-nilai dalam aktualisasi peningkatan karakter kepedulian lingkungan mahasiswa. Tunas Geografi, 8(2), 151-160. https:// doi.org/10.24114/tgeo.v8i2.17190

Prajana, A. (2017). Pemanfaatan aplikasi whatsapp untuk media pembelajaran dalam lingkungan uin ar-raniry Banda Aceh. Cyberspace: Jurnal Pendidikan Teknologi Informasi, 1(2), 122. https://doi.org/10.22373/cs.v1i2.1980

Putra, V. G. V., \& Mohamad, J. N. (2020). A new prediction of daily number of new cases and total number infected for ncovid-19 plague infections in indonesia with the modification of the bernoulli differential equation.

Rahmawati, F. (2016). E-Learning implementation: Its opportunities and drawbacks perceived by efl students. Journal of Foreign Languange Teaching and Learning, 1(1), 1-15. https:// doi.org/10.18196/ftl.111

Retnawati, H., Apino, E., Djidu, H., Ningrum, W. P., Anazifa, R. D., \& Kartianom, K. (2019). Scaffolding for international students in statistics lecture. Journal of 
Physics: Conference Series, 1320, 012078. https://doi.org/10.1088/17426596/1320/1/012078

Retnawati, H., Arliani, E., Hidayati, K., Dhoruri, A., Apino, E., \& Djidu, H. (2020). Have the teachers integrated technology in mathematics learning? Journal of $X i^{\prime}$ an University of Architecture E Technolog, XII(Viii), 720-728.

Riddle, M. S., Connor, B. A., Beeching, N. J., DuPont, H. L., Hamer, D. H., Kozarsky, P., Libman, M., Steffen, R., Taylor, D., Tribble, D. R., Vila, J., Zanger, P., \& Ericsson, C. D. (2020). 2020 Hubei lockdowns. Journal of Travel Medicine, 24(Suppl 1), S63. https://doi.org/10.1093/JTM

Saifuddin, M. F. (2018). E-learning dalam persepsi mahasiswa. Jurnal VARIDIKA, 29(2), 102-109. https:/ / doi.org/10.23917/varidika.v29i2.5637

Saputra, I. G. P. E., \& ; Sukariasih, L. (2019). Penerapan pembelajaran creative problem solving untuk meningkatkan keterampilan berpikir kritis fisika peserta didik kelas XI-IPA 3 SMA Negeri 1 Watubangga. JPFT (Jurnal Pendidikan Fisika Tadulako Online), 7(3), 16-21.

Sari, S. K. (2019). Peningkatan partisipasi belajar mahasiswa dengan sistem elearning edmodo di stain sultan abdurrahman Kepulauan Riau. PERADA, 1(2), 179-189. https:/ / doi.org/10.35961/perada.v1i2.19

Sejati, A. E, Kasmiati, S., \& Ikhsan, F. A. (2019a). The relationship between learning process interactions and student's learning outcomes in environmental sustainability matter geography-social science education subject. IOP Conference Series: Earth and Environmental Science, 282(2019), 012026. https:/ / doi.org/10.1088/1755-1315/382/1/012026

Sejati, A. E., Amaluddin, L. O., Hidayati, D. N., Kasmiati, S., Sumarmi, S., \& Ruja, I. N. (2017). The effect of outdoor study on the geography scientific paper writing ability to construct student character in senior high school. Proceedings of the 5 th SEA-DR (South East Asia Development Research) International Conference 2017 (SEADRIC 2017), 104-108. https:/ / doi.org/10.2991/seadric-17.2017.22

Sejati, A. E., Hasan, M., \& Hidayati, D. N. (2019b). The level participation in efforts mount Kelud eruption disaster mitigation in East Java. Harmoni Sosial: Jurnal Pendidikan IPS, 6(1), 100-106. https:/ / doi.org/10.21831/hsjpi.v6i1.27847

Sejati, A. E., Nasarudin, N., \& Ikhsan, F. A. (2020). The effect outdoor study to the students activeness in senior high school. Geographica, 1(1), 7-12. http:// usnsj.com/index.php/geographica/article/view/1016

Sejati, A. E., Sumarmi, S., \& Ruja, I. N. (2016). Pengaruh metode pembelajaran outdoor study terhadap kemampuan menulis karya ilmiah geografi sma. Jurnal Pendidikan: Teori, Penelitian, Dan Pengembangan, 1(2), 80-86. https:/ / doi.org/10.17977/JP.V1I2.5804

Setiawan, N. (2007). Penentuan Ukuran Sampel Menggunakan Rumus Slovin dan Tabel Krejcie Morgan. November, 1-14. http://pustaka.unpad.ac.id/wpcontent/uploads/2009/03/penentuan_ukuran_sampel_memakai_rumus_slovi n.pdf

Sujatmiko, S. (2017). The translation problem types in translating Indonesia text to English (A case study of translation subject of fifth semester English students âUPY). ELTICS : Journal of English Language Teaching and English Linguistics, 4(1), $1-14$.

Sukariasih, L., Purwana, I. G., Nursalam, L. O., Sahara, L., \& Reskiawan, B. (2019). Improving the skill of physics science process through guide discovery method 
in students at senior high school. 227(Icamr 2018), 341-344. https://doi.org/10.2991/icamr-18.2019.84

Sukariasih, L., Saputra, I. G. P. E., Ikhsan, F. A., Sejati, A. E., \& Nisa, K. (2019). Improving the learning outcomes of knowledge and inquiry skill domain on third grade students of smp negeri 14 Kendari through the guided inquiry learning model assisted by science kit. Geosfera Indonesia, 4(2), 175-187. https:/ / doi.org/10.19184/geosi.v4i2.10097

Thelwall, M., \& Thelwall, S. (2020). Retweeting for COVID-19: Consensus building, information sharing, dissent, and lockdown life. http:/ / arxiv.org/abs/2004.02793

Thorik, S. H. (2020). Efektivitas pembatasan sosial berskala besar di indonesia dalam penanggulangan pandemi covid-19. Adalah: Buletin Hukum E Keadilan, 4(1), 115-120. https:// doi.org/10.15408/adalah.v4i1.15506

Thornton, J. (2020). Covid-19: A\&E visits in England fall by $25 \%$ in week after lockdown. BMJ (Clinical Research Ed.), 369, m1401. https:/ / doi.org/10.1136/bmj.m1401

WHO. (2020). Coronavirus 2019. https:/ / www.who.int/emergencies/diseases/novel-coronavirus-2019

Wirani, N. (2020). The importance of using a web-based learning model to prevent the spread of covid 19. Al'adzkiya International of Education and Sosial 1(1), 17-25.

Yahfizham, Y., Rukun, K., Ihsan, M., Yusti, I., \& Padli, M. I. (2018). Sistem manajemen pembelajaran awan berbasis perangkat lunak sebagai suatu layanan analisis deskriptif. Techno.Com, 17(3), 252-269. https:/ / doi.org/10.33633/tc.v17i3.1698

Yuberti, Y. (2015). Online group discussion pada mata kuliah teknologi pembelajaran fisika. Jurnal Ilmiah Pendidikan Fisika Al-Biruni, 4(2), 145. https:/ / doi.org/10.24042/jpifalbiruni.v4i2.88 